\title{
Front Matter: Volume 10640
}

, "Front Matter: Volume 10640," Proc. SPIE 10640, Unmanned Systems Technology XX, 1064001 (16 July 2018); doi: 10.1117/12.2501410

SPIE. Event: SPIE Defense + Security, 2018, Orlando, FL, United States 


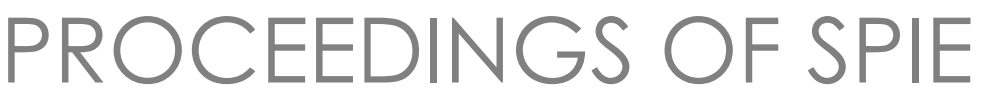

\section{Unmanned Systems Technology XX}

Robert E. Karlsen

Douglas W. Gage

Charles M. Shoemaker

Hoa G. Nguyen

Editors

17-19 April 2018

Orlando, Florida, United States

Sponsored and Published by

SPIE 
The papers in this volume were part of the technical conference cited on the cover and title page. Papers were selected and subject to review by the editors and conference program committee. Some conference presentations may not be available for publication. Additional papers and presentation recordings may be available online in the SPIE Digital Library at SPIEDigitalLibrary.org.

The papers reflect the work and thoughts of the authors and are published herein as submitted. The publisher is not responsible for the validity of the information or for any outcomes resulting from reliance thereon.

Please use the following format to cite material from these proceedings:

Author(s), "Title of Paper," in Unmanned Systems Technology XX, edited by Robert E. Karlsen, Douglas W. Gage, Charles M. Shoemaker, Hoa G. Nguyen, Proceedings of SPIE Vol. 10640 (SPIE, Bellingham, WA, 2018) Seven-digit Article CID Number.

ISSN: 0277-786X

ISSN: 1996-756X (electronic)

ISBN: 9781510617919

ISBN: 9781510617926 (electronic)

Published by

SPIE

P.O. Box 10, Bellingham, Washington 98227-0010 USA

Telephone +1 3606763290 (Pacific Time) · Fax +1 3606471445

SPIE.org

Copyright (C) 2018, Society of Photo-Optical Instrumentation Engineers.

Copying of material in this book for internal or personal use, or for the internal or personal use of specific clients, beyond the fair use provisions granted by the U.S. Copyright Law is authorized by SPIE subject to payment of copying fees. The Transactional Reporting Service base fee for this volume is $\$ 18.00$ per article (or portion thereof), which should be paid directly to the Copyright Clearance Center (CCC), 222 Rosewood Drive, Danvers, MA 01923. Payment may also be made electronically through CCC Online at copyright.com. Other copying for republication, resale, advertising or promotion, or any form of systematic or multiple reproduction of any material in this book is prohibited except with permission in writing from the publisher. The CCC fee code is 0277 $786 \mathrm{X} / 18 / \$ 18.00$.

Printed in the United States of America.

Publication of record for individual papers is online in the SPIE Digital Library.

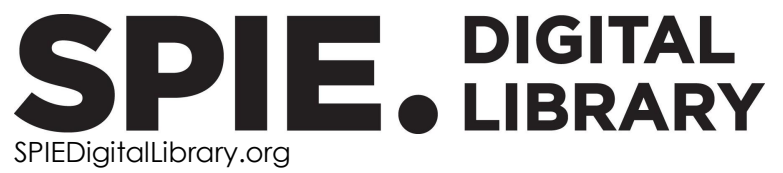

Paper Numbering: Proceedings of SPIE follow an e-First publication model. A unique citation identifier (CID) number is assigned to each article at the time of publication. Utilization of CIDs allows articles to be fully citable as soon as they are published online, and connects the same identifier to all online and print versions of the publication. SPIE uses a seven-digit CID article numbering system structured as follows:

- The first five digits correspond to the SPIE volume number.

- The last two digits indicate publication order within the volume using a Base 36 numbering system employing both numerals and letters. These two-number sets start with $00,01,02,03,04$, 05, 06, 07, 08, 09, 0A, OB ... 0Z, followed by 10-1Z, 20-2Z, etc. The CID Number appears on each page of the manuscript. 


\section{Contents}

$\begin{array}{ll}v & \text { Authors } \\ \text { vii } & \text { Conference Committee } \\ \text { ix } & \text { Introduction }\end{array}$

SESSION 1 PERCEPTION

$1064003 \quad$ Robust homing with stereovision [10640-2]

1064005 Automated, near real-time inspection of commercial sUAS imagery using deep learning [10640-5]

\section{SESSION 2 SPECIAL TOPICS}

1064007 A translation architecture for the Joint Architecture for Unmanned Systems (JAUS) [10640-7]

1064008 MAD-VR: machine learning, analysis, and design in virtual reality [10640-8]

1064009 DRESH: DRone EnSnaring mesH [10640-9]

10640 OA blindBike: an assistive bike navigation system for low-vision persons [10640-10]

$10640 \mathrm{OB} \quad$ A game of timing with detection uncertainty [10640-11]

\section{SESSION 3 ROBOTICS CTA}

10640 OD Robotics collaborative technology alliance (RCTA) program overview [10640-13]

10640 OE An experiment to evaluate robotic grasping of occluded objects [10640-14]

10640 OF Modeling and traversal of pliable materials for tracked robot navigation [10640-15]

10640 OG When does a human replan? Exploring intent-based replanning in multi-objective path planning [10640-16] 
$10640 \mathrm{OH}$ Parallel approach to motion planning in uncertain environments [10640-17]

SESSION 4 NAVIGATION

10640 J Image-aided inertial navigation for an Octocopter [10640-20]

10640 OK UAV vision-based localization techniques using high-altitude images and barometric altimeter [10640-21]

SESSION 5 COLLABORATIVE ROBOTIC TEAMS: JOINT SESSION WITH CONFERENCES 10640 AND 10651

$10640 \mathrm{OL}$ Removing the bottleneck: utilizing autonomy to manage multiple UAS sensors from inside a cockpit [10640-22]

10640 OM Real-time inspection of 3D features using sUAS with low-cost sensor suites [10640-23]

10640 ON Benchmarking a LIDAR obstacle perception system for aircraft autonomy [10640-24]

1064000 Cooperative cognitive electronic warfare UAV game modeling for frequency hopping radar [10640-25]

\section{POSTER SESSION}

10640 OP Automatic voice control system for UAV-based accessories [10640-26]

$10640 \mathrm{OQ}$ Enabling intelligence with temporal world models [10640-27]

10640 OS Stopped random walks and control of uncertain systems [10640-30]

10640 OT Confidence regions with applications to sensing and control [10640-31] 


\title{
Authors
}

Numbers in the index correspond to the last two digits of the seven-digit citation identifier (CID) article numbering system used in Proceedings of SPIE. The first five digits reflect the volume number. Base 36 numbering is employed for the last two digits and indicates the order of articles within the volume. Numbers start with 00, 01, 02, 03, 04, 05, 06, 07, 08, 09, 0A, 0B...0Z, followed by 10-1Z, 20-2Z, etc.

\author{
Alicea, Ryan, OF \\ Alicia, Thomas J., OL \\ Baheerathan, S., OJ \\ Bednarz, David, OB \\ Chen, Xinjia, OS, OT \\ Chester, Dave, 00 \\ Childers, Marshal, $\mathrm{OE}$ \\ Clouse, Rich, 00 \\ Collins, Emmanuel G., Jr., $\mathrm{OF}, \mathrm{OH}$ \\ Cover, Hugh, ON \\ Cutler, Scott, 07 \\ DiBlasi, Michael, $0 Q$ \\ Dornbush, Andrew, $\mathrm{OE}$ \\ Erickson, David R., 09 \\ Erlebacher, Gordon, $\mathrm{OH}$ \\ Fang, Fuqiang, 03 \\ Forrest, Douglas, 09 \\ Gillies, Andy, 05, 0M \\ Goodrich, Michael A., OG \\ Gresak, Erik, OP \\ Grewei, Lynne, OA \\ Hagen, O. K., OJ \\ Harper, Mario Y., OF, OH \\ Hunt, Jodie, 00 \\ Hurwitz, Arnon, OE \\ Jalowiczor, Jakub, OP \\ Jeffers, Mike, 05, OM \\ Karumanchi, Sisir, OF \\ Kaukeinen, Brian, $0 Q$ \\ Kawatsu, Chris, 05, OM \\ Krupansky, Nicholas, OB \\ Ladyko, Kyle, OF \\ Lagali, Christopher, OA \\ Lennon, Craig, $\mathrm{OE}$ \\ Likhachev, Maxim, OE \\ Lyons, Damian M., 03 \\ Matthies, Larry, OF \\ Muench, Paul, OB \\ Nishikawa, Y., OK \\ Ordonez, Camilo, OF, OH \\ Osteen, Philip R., $0 Q$ \\ Ottoson, Tom, $0 \mathrm{O}$ \\ Overell, William, OA \\ Owens, Jason L., OQ \\ Patel, Dilip G., OD \\ Purman, Ben, 05, OM \\ Rahmes, Mark, 00 \\ Rezac, Filip, OP \\ Robison, Christo, $0 Q$
}

Rothrock, Brandon, OF

Rozhon, Jan, OP

Rubini, J., 08

Safarik, Jakub, OP

Saxena, Dhruv Mauria, OE

Serge, Matthew, 09

Shaikh, Meher T., OG

Sheridan, Paul, 05, OM

St. Amant, Robert, $0 \mathrm{Q}$

Stambler, Adam, ON

Strabala, Kyle, ON

Surana, Amit, OL

Taylor, Grant S., OL

Turpin, Terry S., OL

Watanabe, J., OK

Yamamoto, T., OK

Yawata, K., OK

Young, Stuart H., OD

Zhao, Aaron, 05, 0M 
Proc. of SPIE Vol. $106401064001-6$

Downloaded From: https://www.spiedigitallibrary.org/conference-proceedings-of-spie on 25 Apr 2023 Terms of Use: https://www.spiedigitallibrary.org/terms-of-use 


\section{Conference Committee}

Symposium Chair

Arthur A. Morrish, Raytheon Space and Airborne Systems

(United States)

Symposium Co-chair

Ruth Moser, Air Force Research Laboratory (United States)

Conference Chairs

Robert E. Karlsen, U.S. Army Tank Automotive Research, Development and Engineering Center (United States)

Douglas W. Gage, XPM Technologies (United States)

Charles M. Shoemaker, U.S. Army Communications-Electronics

Research Development and Engineering Command (United States)

Hoa G. Nguyen, Space and Naval Warfare Systems Center Pacific (United States)

Conference Program Committee

Jonathan A. Bornstein, U.S. Army Research Laboratory (United States) Jared Giesbrecht, Defence Research and Development Canada, Suffield (Canada)

Larry H. Matthies, Jet Propulsion Laboratory (United States)

Camille S. Monnier, Charles River Analytics, Inc. (United States)

Paul L. Muench, U.S. Army Tank Automotive Research, Development and Engineering Center (United States)

Dilip G. Patel, General Dynamics Robotic Systems (United States)

Brian K. Skibba, U.S. Air Force Civil Engineer Center (United States)

\section{Session Chairs}

1 Perception

Camille S. Monnier, Charles River Analytics, Inc. (United States)

Paul L. Muench, U.S. Army Tank Automotive Research, Development and Engineering Center (United States) 
2 Special Topics

Robert E. Karlsen, U.S. Army Tank Automotive Research, Development and Engineering Center (United States)

Charles M. Shoemaker, U.S. Army Communications-Electronics Research Development and Engineering Command (United States)

3 Robotics CTA

Dilip G. Patel, General Dynamics Robotic Systems (United States)

Stuart H. Young, U.S. Army Research Laboratory (United States)

4 Navigation

Hoa G. Nguyen, Space and Naval Warfare Systems Center Pacific (United States)

Paul L. Muench, U.S. Army Tank Automotive Research, Development and Engineering Center (United States)

5 Collaborative Robotic Teams: Joint Session with Conferences 10640 and 10651

Robert E. Karlsen, U.S. Army Tank Automotive Research, Development and Engineering Center (United States)

Raja Suresh, General Dynamics Mission Systems (United States) 


\section{Introduction}

The Unmanned Systems Technology XX Conference consisted of four sessions and two joint sessions over two days and covered several areas within robotics, primarily from a defense perspective. The conference's list of papers showed a good variety of applications within unmanned systems, with many papers pertaining to unmanned aerial vehicles (UAV's), but also several for ground and sea vehicles. The conference also included a number of papers from international authors.

This year the conference began Tuesday afternoon with a session on Perception, which consisted of four papers: the first on the subject of visual homing and navigation without using a metric map for a ground robot [10640-2], followed by three papers on airfield damage assessment via UAV's. Of the latter, the first described a two air vehicle approach with a quick survey followed by more detailed analysis of suspect sites [10640-4], the second described a convolutional neural network approach to image analysis [10640-5], and the third discussed closed loop control and mission planning for the aircraft [10640-6]. Unfortunately, the first and third airfield assessment papers were not submitted in time for inclusion in the proceedings.

The second session on Tuesday was the Special Topics session, which included papers on: creating an interface between the Joint Architecture for Unmanned System (JAUS) and Multi-robot Operator Control Unit (MOCU) version 4 [10640-7]; a description of an architecture for testing autonomy algorithms [10640-8]; the development of a low-cost physical method to counter UAV's [10640-9]; the creation of a system to assist people with low vision in riding a bicycle [10940-10]; and a game theory approach to ground vehicle mobility [10640-11].

Tuesday concluded with the conference's poster session, which included a paper on voice control of a camera on a UAV [10640-26], the addition of time history information into a world model [10640-27], the connection between stopped random walks and uncertainty in control systems [10640-30], and the construction of confidence regions for feature extraction in high dimensional spaces [10640-31]. The poster session was well attended again this year.

Wednesday morning began with a session from the Army Research Laboratory's (ARL) Robotics Collaborative Technology Alliance (CTA) that started with an overview of the program [10640-13], which includes research to realize operational tempo of robots in unstructured environments, human-robot interactions in complex missions, and mobile manipulation. This was followed by papers on experimental analysis of a combined RGB-D vision and manipulation task [10640-14], modeling of vegetation as spring/damper system with associated measures of trafficability [10640-15], a method for understanding and maintaining 
human intent in robot path planning [10640-16], and development of a fast anytime planning algorithm for a legged platform [10640-17].

The second morning session involved Navigation and consisted of three papers: the first on joint planning and control for UAV's [10640-18], followed by papers on combining visual odometry with an IMU during GPS dropouts for a UAV [10640-20], and methods to correct visual odometry errors for UAV's performing infrastructure inspection [10640-21].

Wednesday afternoon consisted of an informal joint session with Conference 10639, Micro- and Nanotechnology Sensors, Systems, and Applications X, entitled Deep Learning and Neuromorphic Sensing/Computing for Small Autonomous Systems. The session started with an overview of research interests at ARL in machine learning and artificial intelligence, followed by papers on the creation of a database for visual odometry taken with an event-based camera, sparse coding and event-based processing, and advantages of using an event-based camera, such as high frame rate and high dynamic range.

The conference concluded on Thursday morning with a joint session with Conference 10651, Open Architecture/Open Business Model Net-Centric Systems and Defense Transformation 2018. The session was on Collaborative Robotic Teams and seven papers were presented, with the first discussing the challenges associated with autonomous underwater vehicles, including communications and navigation [10651-20]. This was followed by papers on a graph-theoretical approach to swarming UAV's [10651-21], a system for managing a team of UAV's from within a cockpit [10640-22], a comparison between multi-view stereo-vision and LIDAR for autonomous runway damage assessment [10640-23], a nodding LIDAR system for helicopter obstacle avoidance [10640-24], a game theory analysis of radar-based electronic warfare [10640-25], and an auction-based system for decentralized control of autonomous systems.

In its twentieth year, the conference returned to Orlando, Florida (United States) where it began in 1999 as the Unmanned Ground Vehicle Technology Conference with original conference chairs Grant Gerhart, Robert Gunderson, and Chuck Shoemaker. Douglas Gage joined as a conference chair in 2002, Robert Karlsen joined in 2011, and Hoa Nguyen joined in 2017. In 2006, the conference adopted its current name of Unmanned Systems Technology in order to broaden the scope to include unmanned air, sea, and space vehicles. 
Through the years we have seen tremendous advancements in many areas of autonomous systems, both in defense and civilian applications, and expect to see much more in the years to come. We want to thank all those that helped make the conference a success this year and we hope that you enjoy these proceedings and are able to attend and participate in the conference next year in Baltimore, Maryland (United States).

Robert E. Karlsen

Douglas W. Gage

Charles M. Shoemaker

Hoa G. Nguyen 
Proc. of SPIE Vol. 10640 1064001-12 Downloaded From: https://www.spiedigitallibrary.org/conference-proceedings-of-spie on 25 Apr 2023
Terms of Use: https://www.spiedigitallibrary.org/terms-of-use 